\title{
En blød supermagt
}

\section{Martin Marcussen}

\section{Er tiden kommet til endnu en udenrigskommis- sion? Det var det underlæggende spørgsmål for en høring om fremtidens udenrigstjeneste organise- ret af Det Udenrigspolitiske Selskab}

En spadseretur rundt i New York og London kan godt give anledning til forlegenhed. I boghandlernes vinduer udstilles bøger om Danmark og danskerne, i koncertsalene opføres Carl Nielsens samlede værker, politiske forhandlinger i $\mathrm{FN}$ foregår i lokaler indrettede med dansk design og møbler, kraner arbejder hektisk med at opføre dansk arkitekttegnede bygninger, menuerne på selv de bedste restauranter låner heftigt fra Nyt Nordisk Køkken, i bykernerne er man i fuld gang med at Copenhagenize gaderne med bycykler, og i TV følges serier som Borgen og Forbrydelsen.

Tidsskriftet The Economist har for nylig kørt et tema om "The next supermodel. Why the world should look at the Nordic countries". Heri kan man læse, at det ikke kun er kunst, design, film og gastronomi, der udmærker Danmark og resten af Norden. Det gør velfærdsstaten, de offentlige institutioner og ikke mindst de private virksomheder også. Resten af verden burde lære af vikingerne, konkluderer tidsskriftet. Danmark er blevet 'hot' i det store udland, i en grad at magasinet $\mathrm{Mo}$ nocle i sit årlige Soft Power Survey placerede Danmark på en syvendeplads blandt de tyve lande i verden, der mest effektfuldt udøver blød magt. Helt i top er Storbritannien og USA.

Det er svært at få armene ned, når man måler Danmarks internationale tilstedeværelse på disse 'bløde' variable. Men også på den klassiske udenrigspolitiske scene, lader det til, at Danmark måler sig med de bedste. Den amerikanske tænketank 'Center for Global Development' har med det såkaldte Commitment to Development indekset (CDI) rangordnet 27 af verdens rigeste lande baseret på deres dedikation til politikker, som gavner fattige lande. Det interessante er, at der ikke kun tages udgangspunkt i det beløb, der hvert 
år afsættes til udviklingspolitik, men at man derimod også undersøger, hvorledes andre politikker samtænkes med udviklingsindsatsen og dermed kommer til at fremstå som et integreret hele. De syv politikområder, som er vigtige for udviklingslande er udviklingsstøtten, handel, investering, migration, miljø, sikkerhed og teknologi. Indekset måler altså dét, der indgår som et meget centralt element $\mathrm{i}$ den danske udviklingsstrategi, nemlig samtænkning.

Det viser sig da også, at Danmark sammenlagt rangerer som nummer ét i 2012. Danmarks udviklingssamarbejde er altså verdens bedste!

Også European Council on Foreign Relations (ECFR) har et godt øje til dansk udenrigspolitik. I deres European Foreign Policy Scorecard 2012 placerer man Danmark blandt de såkaldte 'leaders' i den europæiske udenrigspolitik. Helt i top er Tyskland og Frankrig, der på de fleste punkter sætter kursen i europæisk udenrigspolitik, men Danmark er altså også godt med. I hvert tilfælde hvis man tager landet størrelse i betragtning. Selvom man nok kan smile lidt af udtrykket 'punching above one's weight', må man i det hele taget sige, at det er netop, hvad Danmark gør i disse år på den internationale scene.

I lyset af udenrigspolitikkens og den danske samfundsmodels åbenlyse succes'er på den internationale scene kan det synes paradoksalt, at der nu igen er opstået en diskussion om, hvorvidt den danske udenrigstjeneste er indrettet på den rigtige måde.

Det er bestemt ikke nogen ny debat. Udenrigstjenesten har i de seneste år levet en omtumlet tilværelse, der er blevet udpenslet i de danske medier (se boks side 56) og ikke mindst i nærmest konstante krav fra finanslov til finanslov - om nedskæringer og omstruktureringer.

\section{Fire udenrigskommissioner}

Også i et endnu længere historisk perspektiv har udenrigstjenesten været til debat. Gennem det seneste århundrede er der blevet nedsat fire udenrigskommissioner (1906-1908; 1919-1921; 1957-60; 1989-1990). Hver for sig har de forsøgt at analysere den eksisterende udenrigspolitiske organisation og -strategi i lyset af landets indre og ydre omgivelser. Selvom den moderne udenrigstjeneste ikke har mange lighedspunkter med udenrigstjenesten fra forrige århundredes begyndelse, er det alligevel overraskende, hvordan analysen af Danmarks strategiske omgivelser er forblevet konstante.

I 1921 var det eksempelvis, lige som det er tilfældet i dag, den økonomiske krise, der havde fortrin i den udenrigspolitiske debat: "For et Land som Danmark er det jo indlysende, at ... dets Udenrigsministerium i ganske særlig grad maa skyde Landets Økonomi i Forgrunden" (Kommissionsbetænkningen af 28. januar 1921, p. 11). Det blev den- 


\section{BAGGRUND}

gang fremhævet, at Danmark er et land i intens vekselvirkning med hele verden, hvilket nødvendiggør at ministeriet gives en organisation, der svarer til disse nye vilkår. Ændringer der finder sted meget langt fra Danmarks grænser, og som landet ingen indflydelse har på, har fremkaldt en "revolutionær omlægning af vort Erhvervsliv" (ibid. p. 14), konstaterede man. Hvor det før nærmest udelukkende var nærområderne, der var af betydning for danske erhvervsinteresser, er det nu konkurrencen der hidrører fra den anden side af kloden vi skal bekymre os om. Dem der var "tidligere Kunder af Europa og Amerika er begyndt at forsyne sig selv og at ind- træde i den verdensomsætning, der bliver tilbage, som Konkurrenter til den hvide race" (ibid. p. 35). Ser man bort fra den i nutidens målestok noget politisk ukorrekte formulering er datidens analyse ikke så langt fra den, vi i dag laver vedrørende BRIK-landene.

Og hvordan er det nu at optræde som et lille land i en meget globaliseret og urolig verden? Sagen er den, blev det fremhæuet i 1921, at de nye eksistensbetingelser både betyder, at vi har fået nye udfordringer men så sandelig også nye muligheder for at opfylde vore udenrigspolitiske målsætninger. Det er slut med at føre en "Stillebens-Tilværelse" som i 1860'erne (ibid. p. 15).

\section{Udenrigstjenesten i danske medier}

2001: Weekendavisen, "Dyre diplomater", 8. juni.

2002: TV2, "Det dyre diplomati", 7. marts.

2003: Weekendavisen, "Diplomatiets tabte ære", 25. april.

2003: Ritzaus Bureau, "Storvask i diplomatiet", 24. august.

2004: Politiken, "Farvel til dansk udenrigspolitik", Christian Friis Bach og Martin Lidegaard, 20. januar.

2005: Børsen, "Uvejr i udenrigstjenesten”, 23.-25. september.

2006: Berlingske Tidende, "Den danske udenrigstjeneste skal nytænkes”, 15. februar.

2008: Politiken, "Tid til en udenrigskommission"? Daniel Korski, 16. december.

2009: Berlingske Tidende, "Udenrigstjenesten rystes af ny struktur", 25. februar.

2010: Børsen, "Kulturrevolution i diplomatiet", 12. marts.

2011: Berlingske Tidende, "Det er tid til en udenrigskommission", Niels Erik Andersen, 17. oktober.

2012: Jyllandsposten, “Udenrigsministeriet i havsnød”, Lykke Friis og Søren Pind, 1. september. 
Nu må der føres en aktivistisk politik under hensyntagen til den intense vekselvirkning med verdensøkonomien og konstant med øje for erhvervslivets interesser. Ja, faktisk er der mange fordele forbundet med at være en småstat på den globale arena: "vi har på to Maader en fordel frem for store Lande under de nuværende Forhold, der begge er begrundet i vor Lidenhed. Den gør, at det er et minimum af verdensomsætningen, der behøves, for at vi skal kunne leve, og at vi, hvor vi optræder i fremmede Lande, ikke vækker Frygt, hverken i økonomisk eller politisk Henseende" (ibid. pp. 48-9).

Men for at vi kan udnytte disse småstatsfordele må vi se at komme os over vores eget lilliput syndrom. Selvom vi er små og selvom opgaverne er store er "de nye opgaver, som stilles os, ... ikke for store for vor Intelligens" (ibid. p. 49). Det konstateres også, lidt mere melodramatisk end man i dag vil formulere sig i en betænkning, at "Opgaverne er Tidens, og den retter sig ikke efter os. Formaar vi ikke at tilpasse os til den, hører vi i sandhed til de smaa Folk, ikke i Omraade og Tal, men i menneskelig Lødighed” (ibid. p. 49). Det er op til os selv om vi vil smede mens jernet er varmt, eller om vi vil forpasse en chance. Hvis passiviteten bliver udkommet af denne refleksion kan vi ikke undskylde os med vores fysiske lidenhed, men derimod med vores eget sløvsind: "uden menneskelig Indsigt kan der intet udrettes" (ibid. p. 50).

I 1921 anbefalede man i øvrigt, at udenrigstjenesten organiserede sig som enhedsorganisation. I datidens parlør betød dette, at man skal forsøge at integrere erhvervslivets interesser og handelspolitiske forhold i alle andre aktiviteter, der varetages af Udenrigsministeriet. Det kender vi fra debatten i dag. I dag forsøger vi at integrere erhvervslivets interesser i vores bistandspolitik, borgerservice, miljøpolitik og sikkerhedspolitik. I udetjenesten indebærer ideen om en enhedsorganisation, at man skal forsøge at samle de konsulære tjenester med Gesandtskaberne, dvs datidens ambassader (ibid. p. 56). Også denne problematik kan vi nikke genkendende til i dag. Endelig betyder begrebet enhedsorganisation at man skal tilstræbe at fusionere "den indre og den ydre Tjeneste" (ibid. p. 57). Al den integration leder ud i et forslag til en slags matrixorganisation, som vi også kan se antydningen af i Udenrigsministeriets moderne centerbaserede organisationsform. Blandt 'centrene' konstateres interessant nok, at der i datiden, såvel som i dag, fokuseres rigtigt meget på værdien af pressebureauet og dennes relationer til den øvrige centraladministration, til den danske befolkning og ikke mindst til udlandets befolkninger og deres presse (ibid. pp. 75-9). Også dengang havde man tanker om offentlighedsdiplomati. 
Det øgede fokus på erhvervslivets behov indebærer naturligvis også en styrkelse af repræsentationen i Østasien og endvidere en oprettelse af en serie midlertidige og let bevægelige poster, der senere vil kunne inddrages eller gøres permanente: “i mange af de Lande, som dansk Erhvervsliv maa have sin opmærksomhed særlig henvendt paa i den kommende Tid, er der ingen eller en højest utilstrækkelig Repræsentation.

Kommissionen finder ikke den nuværende Ordning forsvarlig" (ibid. p. 56). Land for land argumenteres der for, hvorfor der bør oprettes nye Gesandtskaber: "Forrykkelsen af de økonomiske Verdensforhold ... rummer farer ... og Chancer" (ibid. p. 61). Timingen for at opbygge en ny og effektiv og fleksibel udenrigstjeneste er den helt rigtige, fremhæves det. Det er for at undgå de mange farer og for at udnytte de nye chancer, at der skal oprustes på Danmarks eksterne repræsentation: "Verdensøkonomien er af Lave, og ... det gælder om at opdage hver Chance, der byder sig for Erhvervslivet" (ibid. p. 60). Det understreges, at selv ikke den bedste udenrigstjeneste kan erstatte "det private initiativ og den enkeltes fortagsomhed" (ibid. p. 61). Erhvervsfremmeopgaven består udelukkende i hjælp til selvhjælp.

Ud over disse strategiske punkter anvendes der i betænkningen også en meget stor mængde sider på at diskutere løn, uddannelse, karriere og boligforhold for udenrigstjene- stens ansatte. Også disse temaer har været kimen til mange skærmydsler gennem årene.

\section{Endnu en udenrigskommission?}

Spørgsmålet er, om tiden er kommet til endnu en udenrigskommission? Det var det underlæggende spørgsmål i en fire timers lang høring om fremtidens udenrigstjeneste organiseret af Det Udenrigspolitiske Selskab den 15. januar 2013. Blandt oplægsholderne var blandt andet repræsentanter for Udenrigsministeriet (Claus Grube og Poul Skytte Christoffersen), medieverdenen (Bo Lidegaard) og det private erhvervsliv (Steen Riisgaard, administrerende direktør for Novozymes og Torben Ørting Jørgensen, pensioneret kontreadmiral og nuværende General Manager i Maersk Broker). I en stuvende fuld sal på Institut for Statskundskab, Københavns Universitet, der vidner om betydelig interesse for udenrigstjenestens udfordringer og fremtidige muligheder, sad blandt andet Niels Ersbøll, Jens Christensen, en lang række pensionerede ambassadører og naturligvis formanden for Det Udenrigspolitiske Selskab, MF Lykke Friis (V).

"Udenrigsministeriet har ændret sig mange gange siden 1770, hvor grundstenene blev lagt”, slog Claus Grube fast i sit indlæg. "Når verden ændrer sig, har tjenesten ændret sig parallelt hermed. Det interessante er, at udenrigstjenesten i dag har 
samme målsætninger, som den havde i 1770: økonomisk vækst og jobskabelse i bred forstand. Hele organisationen er gearet til at bidrage med en fælles løsning på dette overordnede samfundsproblem. Det er i lyset af vækst og beskæftigelsesproblematikken, at vi skal vurdere den nuværende stærke interesse for vores engagement i BRIK-landene. Det er rigtigt, at EU og USA er målet for næsten 80 pct. af vores samlede eksport, men det vil ikke fortsætte.

Væksten finder sted i andre verdensdele. Også vores klimapolitiske satsning skal ses i dette lys". Danmark er, ifølge Claus Grube, en førende aktør i 3GF (Global Green Growth Forum). Sammen med Sydkorea og Mexico er formålet at samle alle relevante offentlige og private aktører, der kan bidrage til at skabe en overgang til en decideret grøn økonomi.

"I dag har Udenrigstjenesten den størrelse som Udenrigstjenesten skal have", mener Grube. "Erfaringerne med at åbne og lukke ambassader i tide og utide har ikke været gode". Han peger på Generalkonsulatet i Hamborg som eksempel. "De økonomiske gevinster har været for små og de politiske omkostninger for store. Kravet er derfor, at vi gentænker den måde, de eksisterende ambassader fungerer på", siger Grube. Der anvendes hvert år cirka 600 millioner kroner på udetjenesten - eksklusiv lønninger. Med omtrent 100 repræsentationer betyder det, at der gennemsnitligt anvendes seks millio- ner kroner per repræsentation. "I realiteten betyder dette, at langt de fleste danske ambassader koster 1-3 millioner kroner at drive. Det er meget små ambassader", forklarer Grube.

Poul Skytte Christoffersen giver sin egen belgiske ambassade som eksempel. Ud over ham selv er der fire lokaltansatte på ambassaden. To tager sig af eksportfremme, én tager sig af det konsulære, og den sidste dækker alt andet forefaldende arbejde. "Der kan ikke skæres længere ind til benet. Så må man hellere lukke og slukke", mener Skytte Christoffersen.

\section{Eksportfremme}

"Vi hører til dem, der går åbent frem og siger, at vi ikke ønsker besparelser i udenrigstjenesten", understreger Steen Riisgaard. "Vi kan kun være glade når vi hører at vækst og beskæftigelse er blevet målsætning nummer ét i Danmarks diplomatiske indsats verden over. Novozymes har brug for en stærk diplomatisk tilstedeværelse i udlandet. Selvom vi selv har ansat en mængde Public Affairs medarbejdere til at varetage vores politiske interesser rundt omkring i verden, har vi behov for ambassaderne".

Det bekymrer imidlertid Steen Riisgaard, at ikke alle ambassader har været lige gode til at fange budskabet om muligheder i og kravet om professionel og strategisk eksportfremme. "Der er ambassader, 


\section{BAGGRUND}

der kaster glans over vores virksomheds tilstedeværelse i udlandet. Det skal ikke underkendes. Vore amerikanske kolleger har eksempelvis ikke den mulighed at få deres ambassader til at hjælpe dem med pomp og pragt og kongekrone. Men man kan gå et skridt videre end det. Der er meget stor forskel fra ambassade til ambassade med hensyn til strategisk at tænke erhvervslivets interesser ind i alt det diplomatiske arbejde. Nogle gange ændres det strategisk blik for erhvervslivets interesser, når der ankommer en ny ambassadør”. Ifølge Steen Riisgaard skulle det være en selvfølge, at erhvervslivets interesser blev indtænkt i klimapolitikken, udviklingspolitikken og sikkerhedspolitikken.

Også Torben Ørting Jørgensen mener, at budskabet om vækst og beskæftigelse tager sig godt og rigtigt ud. Bekymringen for ham er imidlertid, at Udenrigsministeriet ikke helt formår at arbejde sammen med andre offentlige såvel som private aktører i realiseringen af dette mål. "Der er langt imellem nogen, der synes, at det er fedt at arbejde sammen med UM", mener han. Han eksemplificerer påstanden ved at referere til det muligvis tabte erhvervspotentiale, der eksisterer i henholdsvis Irak, Libyen og Grønland.

En nydannelse for den danske udenrigstjeneste udfolder sig med bestemmelserne i Lissabon-traktaten vedrørende den fællesudenrigstjeneste (FUT'en). "Vi ved endnu for lidt om, hvordan EU's fælles udenrigstjeneste kommer til at se ud. Det vil i hvert tilfælde vare tre til fire år førend grundstrukturen er helt på plads", forklarer Poul Skytte Christoffersen. "Der er ganske få udenrigstjenester, der aktivt tænker FUT'en ind i de reformer, der gennemføres overalt i øjeblikket. Typisk er det finansministerierne, der refererer til FUT'en som en oplagt mulighed for at lave besparelser i de nationale udenrigstjenester. Men i praksis er der ikke meget, der direkte kan overføres fra den nationale udenrigstjeneste til den europæiske

Figur 1: Bemanding af de permanente representationer i Bruxelles, januar 2013

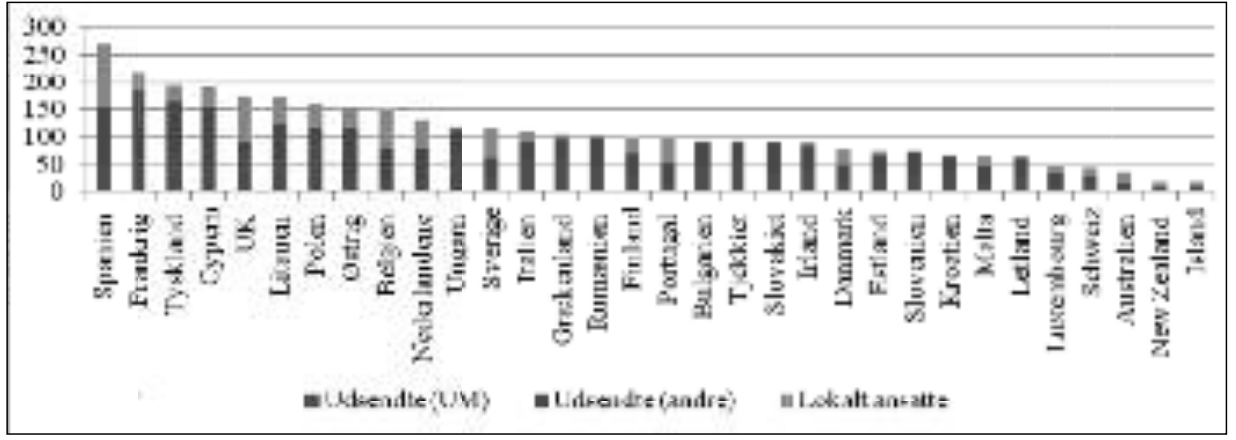


udenrigstjeneste”, forklarer Skytte Christoffersen. "I øvrigt er FUT'en mandskabsmæssig ikke særlig stor mindre end den hollandske udenrigstjeneste. Men det interessante for os er, at den har EU-delegationer i 140 forskellige lande".

\section{Dansk indflydelse på FUT'en}

Dét at FUT'en endnu ikke er fuldt udviklet, kan være en dansk fordel. Vi kan bruge tiden til at få indflydelse på denne tjeneste inden de store medlemslande helt overtager forretningen. "Det halter imidlertid med dansk indflydelse", mener Skytte Christoffersen. "For det første kan vi være meget bedre til at sende danske diplomater ind i den europæiske udenrigstjeneste, for det andet kan vi være meget bedre til at spille ind i den politiske- og sikkerhedspolitiske komité (PSC), hvor den europæiske udenrigspolitik fastlægges.

Vi har imidlertid et alvorligt kapacitetsproblem. Målt på antallet af udsendte diplomater har kun Malta og Luxembourg en EU-repræsentation, der er mindre end vores. Selv de meget mindre baltiske lande har større diplomatisk repræsentation i EU-systemet, end vi har", siger Skytte Christoffersen (Figur 1).

Claus Grube supplerer og siger, at de mange sparekrav nærmest skubber de europæiske udenrigstjenester i armene på FUT'en. Men måske er det ikke helt dårligt, siger han: “FUT'en giver os øget frihed til at prioritere mellem opgaver. Nogle konsulære rutineopgaver kan simpelthen bare overdrages til FUT'en. FUT'en giver os endvidere adgang til en større palette af instrumenter. Når vi pooler ressourcer, er det simpelthen muligt at gøre mere, end vi hver især kan gøre enkeltvis. Endelig er der jo de stordriftsfordele, der kan høstes gennem samarbejde i den fælles udenrigstjeneste”.

Der kom ikke ved høringen noget entydigt svar på, hvorvidt der er behov for en ny udenrigskommission. Alle er enige om, at verden ændrer sig med en hastighed og i et omfang, der gør det vanskeligt helt præcist at angive konkrete, holdbare og fremadrettede løsninger for udenrigstjenesten. Problematikken er ikke enestående. I samtlige de nordiske lande samt hos de allerstørste udenrigspolitiske aktører som eksempelvis USA, Storbritannien, Frankrig og Tyskland er debatten den samme: hvordan har globaliseringen, afslutningen på den kolde krig og den europæiske integrationsproces påvirket diplomatiet, og hvilke organisatoriske og finansielle konsekvenser skal dette have for udenrigstjenesten? Skal vi have mere eller mindre udenrigstjenesten, eller skal vi bare have en anden slags udenrigstjeneste? Ingen tvivl om, at det sidste ord ikke er sagt i den forbindelse.

Martin Marcussen er professor ved Institut for Statskundskab, Københavns Universitet. 